\title{
ALFRED FRENCH
}

\section{Nezval's Amazing Magician: A Czech Shamanist Epic}

From the labyrinth of literary revaluations to which modern Czech literature has been subjected, the work of the gifted but unpredictable lyric poet Vítézslav Nezval (1900-1958) has emerged relatively unscathed. His literary career was a bewildering trail of shifting allegiances and paradoxical novelties -from Expressionist infantilism to elegant sophistication, from Dadaist antiart to obsequious socialist realism: an anarchist in his youth, a surrealist in middle age, he ended as a laureate of the Czechoslovak Communist Establishment. $^{1}$

At the age of twenty Nezval came to Prague for university studies. Always a loner, he led a solitary life in the big city. His early poems are full of nostalgia for his Moravian home and lost childhood, sometimes recalled with more than a touch of childish nightmare. ${ }^{2}$ Prague in the early twenties was a place of tumbling pedestals and mushrooming social manifestoes: the newly silenced guns and the freshly inaugurated state seemed to be an earnest of a new start, and the end of a world discredited. ${ }^{3}$ It stood condemned by the obscenity of the war it had produced (the fact that the Czechs had actually benefited from the war by gaining independence perhaps increased their feelings of guilt). The culprit was found in the social system, economic injustice, and an imperial system which had produced the nightmare alienation of Kafka's Prague. Complex problems encourage the illusion of simple solutions. News

1. Several monographs have appeared on Nezval's work, for example, Fedor Soldan, O Nezvalovi a poválečné generaci (Prague, 1933), and Antonín Jelínek, Vitězslav Nezval (Prague, 1961). Jiři Svoboda provides an intimate portrait of the poet in his Pritel Vitězslau Nezval (Prague, 1966). There is also a bibliography edited by Milan Blahynka and Jaroslav Nečas, Vitězslav Nezval (Prague, 1960). Perhaps the best selection of Nezval's poetry is Vitězslav Nezval: Podivuhodny kouzelnik, edited by the poet Milan Kundera (Prague, 1963). Of the many books concerned with the literature of the period, perhaps the best single study is František Xaver Salda's $O$ nejmladši poesii české (Prague, 1928), now most readily available in Salda's Studie z české literatury (Prague, 1961), to which reference is subsequently made in this article.

2. Nezval's first book of verse was Most (Prague, 1922). His earliest poems were written at the age of sixteen.

3. For the literary atmosphere of Prague in the early twenties see F. X. Salda, Krásná literatura česká v pronim desetileti republiky (Prague, 1930); Květoslav Chvatík, Bedřich Václavek a vývoj marxistické estetiky (Prague, 1962); Zdeněk Kalista, "Počátky české literarní avantgardy," Annali dell'Istituto Universitario Orientale (Naples, 1965); František Götz, Anarchie v nejnladši česke poesii (Brno, 1922) ; Jan B. Capek, Záreni ducha a slova (Prague, 1948), pp. 449-59; and Alfred French, The Poets of Prague (Oxford, 1969). 
from Russia indicated that social revolution was about to sweep the world clean with the force of a tidal wave. Revolutionary political slogans became confused with revolutionary art forms; and literary styles changed with remarkable speed. (In 1920 Futurism seemed to be the very latest thing. When Marinetti visited Prague two years later, he found himself regarded by the young Czech avant-gardists as already passé.) The idea of a fresh start for mankind lent attraction to contemporary Expressionism, with its assault on the senses and its return to childlike art forms: among the Czechs it appealed to a spirit of Franciscan humility and universal love, typical of that period's youthful idealism.

From this atmosphere emerged Czech so-called Proletarian art, mainly poetry. ${ }^{4}$ It was seriously engaged in the task of preparing for the revolution: the poems included slogans and dramatic gestures; their mood was of compassion and anger; thematically they were concerned with slums, factories, and the heroism and tribulations of the workers. Older poets contributed to the movement, but its star was the young Jirí Wolker. ${ }^{b}$ Aiming to reach an audience of workers, the poets wrote in traditional, rather simple, and at times sentimental style, abjuring all experimentation and innovation. Thus their work, although intended to be "progressive," was from a formal point of view rather conservative, and this was one of the things which soon began to dismay the young poets. Another disappointment was the gradual realization that the working class is not a particularly receptive audience for poetry, and rarely choose to spend their leisure time reading about factories.

The Proletarian movement was already in a state of crisis in 1922 when Nezval came into personal contact with its leading exponents. ${ }^{6}$ Although a way-out radical himself, he did not favor the Proletarian style in literature, finding it too rhetorical and unimaginative, overburdened with ideology and uplift. In April he happened to attend a meeting of the literary avant-gardists

4. Chvatík, Bedrich Václavek, pp. 42-71; Antonín Matěj Píša, Proletár̆ská poesie (Prague, 1936); Stanislav Kostka Neumann, O umèni (Prague, 1958). In English there is a lighthearted article by Karel Capek on Proletarian art in In Praise of Nezuspapers (London, 1951), pp. 123-32. The most successful poetry collections in the style are by Josef Hora, Pracujicí den (Prague, 1920), and Jiří Wolker, Těgká hodina (Prague, 1922).

5. For the work of Wolker see Vitězslav Nezval, Wolker (Prague, 1925), reprinted in Nezval's collected works (Dilo XXIV, Prague, 1967, pp. 17-33) ; Zdenèk Kalista, Kamarád Wolker (Prague, 1933); Ladislav Kratochvil, Wolker a Nezval (Prague, 1936); Milan Blahynka and Jiří Cutka, Nezval a Wolker (Prague, 1964) ; Přemysl Blažiček in Ceská literatura, 11 (1963): 449-72 ; Alfred French, "Wolker and Nezval," in Miloslav Rechcigl, Jr., ed., Czechoslovakia Past and Present, 2 vols. (The Hague and Paris, 1968), 2:983-92.

6. Details of Nezval's early life in Prague and his contacts with the literary radicals appear in his memoirs, $Z$ mého života (Prague, 1959), pp. 88-121. See also Zdeněk Kalista, Tvár̆e ve stínu (Prague, 1969), pp. 195-216. 
at which the poet Seifert read a paper on New Proletarian Art. ${ }^{7}$ Nezval, who had gone to criticize, found himself applauding the group's "new look." Seifert affirmed the need for social commitment in literature, and above all the need to re-establish contact with the masses: to do this he suggested a new program. He regretfully admitted that tendentious art was often rubbish-like the ephemeral pamphlets of any revolutionary period. A people's art had to find its way to them through their own interests: at the present juncture sentimental novels of travel, cowboy films, and Jules Verne-type adventure yarns were closer to the hearts of the proletariat than the Communist Manifesto. Modern exoticism, sensational science fiction, the visual excitements and horrors of the silent films-this was the raw material of modern urban folklore. It was on this basis that literary radicals must build, if they wished to enter the imaginative world of the people. A novel element in the program was the ambitious attempt to incorporate highbrow and lowbrow art into something new, in which the revolutionary writer would find again his lost popular audience. Before the writer could revolutionize society, he first must revolutionize art: "We see," said Seifert, "the need to replace today's idealistic Bergson-Croce art theory with a new aesthetic, based on the essential principles of Marxism. Not stories of industrial poverty, not pictures of mines and foundries, but of tropics and faraway lands; poems of free, adventurous life that bring to the worker not the realism that crushes, but the realism, the visions, that bring life and strength."

The debate took place at a time when Prague was invaded by a wave of Western films; when fantasy yarns filled the lurid magazines, and when Negro jazz was bringing to Prague the exotic rhythms of the New World. ${ }^{8}$ The young poets were as fascinated by the new pop art as other people were. They were avid readers of detective stories, and regular cinema patrons. The stars of the early American films were among their most endearing folk heroes: their pictures adorned Czech avant-garde journals, and Charlie Chaplin was made an honorary member of the Devertsil group. ${ }^{9}$

The paper which Seifert presented that evening was the first shot in a

7. The paper was subsequently published in the volume Revolučni sbornik Devětsil [Revolutionary Volume Devětsil] (Prague, 1922). Devětsil was the name of the group. The paper, which was later attributed to the theoretician Teige, was reprinted in the collection Karel Teige: Výbor z dila I (Prague, 1966), pp. 33-63. For a discussion of the movement see the essay "Nové umèní," by Vratislav Effenberger, in the same volume (pp. 575-619).

8. For a picture of Prague's popular culture at the time see Svatava Pírková-Jakobson, "Prague and the Purple Sage," Harvard Slavic Studies, 3 (1957): 247-87.

9. "The cinema is the true encyclopedia of modern art, a universal spectacle and universal lesson. In the cinema we enjoy ourselves and are happy. It is the Bethlehem from which issues the salvation of modern art" (Karel Teige, "Uměni dnes a zítra," in Revolučni sborník Devětsil). 
new literary campaign which produced the artistic movement to be known simply as Poetism-bizarre, popular, humorous, futuristic, and above all entertaining. ${ }^{10}$ The ideas of the group had been anticipated by Nezval himself, and after the meeting he revealed to Teige that he already had in manuscript a long poem written in the spirit of the new art. ${ }^{11}$ At the time Teige was preparing for publication a volume of the collected work of the group. After reading Nezval's poem, he offered to publish it in the same issue as the paper whose thesis it illustrated. In the autumn of 1922 it duly appeared. The poem was entitled Podivuhodný kouzelnik (The Amazing Magician). It embodied the revolutionary attitudes, even the slogans, which formed the political platforms of the group, and incorporated their futuristic views on art. Its framework was that of an epic poem, but its content outdid the fantasies of the screen, by which it was so clearly influenced.

The poem opens with an enigmatic prelude, whose meaning unfolds only with the progress of the epic:

O nové kultư̌e sníš a já nově ti v proměnách zpivám fontáno $s$ tygřicí jež jsi náhrobkem tohoto děcka troubil postilión a koníci běželi $\mathrm{k}$ nivám rozplakat oči hvězd Má píseñ je duhou—s ní kráčej

New is the culture you dream of: new variations I sing you, tigress-decked fountain that rises over the grave of that dead child. Loudly rang out the post-horn. Horses raced on to the meadows, charming to tears the stars. Come, march to the rainbow I sing you!

The prelude hints at the poet's image of his role-not as teacher, but as prophet, a giver of oracles wrapped in mystery.

The poem is divided into seven parts-the magic number which occurs repeatedly in its action. Part 1 tells of the magician's genesis. Action begins in the real world, and is told in the first person. It is Prague in the evening. The poet begins the journey which will take him into the world behind the looking glass:

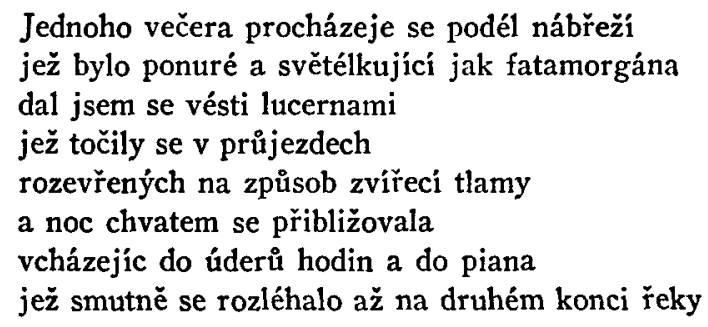

10. The best single book on the Poetist movement is the collection Poetismus, ed. Květoslav Chvatík and Zdeněk Pešat (Prague, 1967), with an extensive bibliography.

11. Nezval, $Z$ mého života, pp. 88-90. Nezval recalled his discussions with Teige on their walks through Prague in the essay "Kapka inkoustu," which is reprinted in Nezval's collected works (Dílo XXIV, pp. 173-84). Nezval used the same passage in his review of Teige's book Film (1925). 
One evening I walked by the river in the gloom like a shimmering mirage, following the lead of the street lamps twisting through alleys opening like jaws of a beast.

Night came down rushing upon me with the chiming of clocks. A piano came poignantly echoing over the water...

Reality disappears with the city streets: a desolate landscape reveals a great mound, on its side a convent. Like the vast heap of futility that is European culture, the mound supports the stern and joyless symbol of the Czech spirit. In the moonlight the air shimmers like a movie screen; and figures appear, moving over it. There is a nun. From the chapel wall, Christ, in seven guises, looks down upon her. Beautiful in face, she is unaware of her beauty: untouched and unseen by men, her beauty is barren. Like a flower whose petals close at a touch, she is betrayed at last by the odorless breath of the mound's sick blossoms: thus the magician is conceived.

Part 2 of the poem traces the magician's lineage. The mound with its rotting flowers is the tip of a structure which stretches through many layers down through the earth, until it reaches the light of the sickle moon at the antipodes. Amid the layers of reality which lie below the magician a fountain seeths, always trying to force its way upward into the light of day. Between it and the surface lie memories and visions, frightening to those who glimpse them as dreams and hallucinations and thrust them down out of sight. From the earth comes strange music, the song of creation beaten out by the underground fountain seeking its liberation.

The third part introduces the Lady of the Lake, whose destiny is entwined with that of the magician. He sees her at birth; seven years later he goes out into the world; after seven more years he returns to tell her his adventures. His childhood was haunted by the vision of a cat staring at him through a window. $\mathrm{He}$ is filled with a sense of loss which he cannot explain. He carries the memory of a dead playmate, and flies from one daydream to another in search of the antidote for his feeling of loneliness and guilt. His vision of romance, the Lake Lady, disappears beneath the waters without a word.

Part 4 tells of the revolution: it is here that the magician hopes his restless search will find an end. He moves among the crowds, gay with cockades, and leads them cheering to the barricades. It is a time of triumph and carnival; the day of liberation is at hand. But the morrow of revolution finds the magician again restless. Social revolt is, after all, not the magic which will release him.

Part 5 opens with sleep, and the old recurring dream of the cat. The 
magician awakes with a terrible cry, and before him is the Lake Lady. Recognizing in her now a mother, now a lover, he confesses his need and his sense of loss. But her words make no logical sense. Totally confused in her presence, he can find contact with her only through the act of love. Then he is again alone.

In part 6 the magician finds and reveals his powers. He enters the house of sickness as a healer, and finds his way to the inner sanctum where the dead lie. Seeking to relive his triumph at the barricades, he organizes the dead in revolt against death. But death is too strong for him: the corpses are unmoved. Yet it is in their presence that he finds enlightenment. He is in a bronze forest, with crystal cliffs, and glass fish gliding below the water; somehow his quest for life has reached its climax. He cries in terror, and his own voice answers him:

\begin{abstract}
Vlastní zvuk ozvěnou z dảlky se posmívá Chceš-li být živ shnij za živa za živa tělo se rozpadne moudrost však musí zbýt chceš-li ji poznati za živa musiśs shnit

The echo of his voice mocks him from far away: "If life is your desire, rot, rot, your living clay! The flesh disintegrates, yet wisdom will survive: if wisdom is your goal, then rot, alive!"
\end{abstract}

The magician now begins his true apprenticeship; seeking life through death he passes through seven metamorphoses. In Greenland, death finds him: an iceberg carries him for burial to the great canyon, where he enters the form of a holy statue. In Indo-China he is worshipped, but the great statue falls to dust, and from it pours an army of Negroes. Below the earth a regiment of miners burrow through a relay of exploding shafts. The next scene is a Hollywood fantasia. The new world of art is peopled by Fairbanks, Apollinaire, and Picasso. Poetry had given way to jazz and the rhythm of the blues. The magician leaves this delightful land, remembering his quest. His last journey is to the island of the lepers, where he arrives as a redeemer. Joining the caravan of death he sails on the marble boat to the underworld, the source of the moonlight which had always beckoned him. From the moon he looks down on the earth and sees his own image. In the midst of the city square a fountain spurts into the air. Upon his petrified body the Lady of the Lake crouches in the form of a tigress. Liberated at last, the fountain of life sings its song of creation in a movement which will never be stilled.

The final act of the poem returns the poet to the real world of Prague and makes some interpretation of the preceding fantasies. Behind the façade of dead normality an endless struggle goes on for liberation of the heart and the 
imagination. From the fragments of today's world men are fashioning a new star of freedom. ${ }^{12}$

The Amazing Magician was a startling, apparently chaotic poem. As socially committed as the verses of the Proletarians, it differed dramatically from them in style, mood, and intention. Revolution, to Nezval, was identified not merely with a change in the legal arrangements or the economic system, but, more important, with a liberation of the spirit, which he associated with modern art. Humor, quite lacking in the verses of Wolker, and in fact an unusual feature of Czech verse altogether, had become almost an organizing principle in the work of Nezval. Whereas revolution to the Proletarians was a symbol for sacrifice and endurance, to Nezval it was a sign of gaiety, a time when inhibitions could be cast aside, as during a carnival. The revolution, which to Wolker seemed the main purpose of his art, became a gay theme to Nezval-especially appropriate to poetry because it reversed the existing order and released vital energy. It was not a discipline of ascetic endurance but a pandemonium of the spirit. ${ }^{13}$ And the style of the poem was closer to a cinema knockabout than to traditional literature.

Nezval's poem was aggressively modernist ; yet in some ways it was surprisingly traditional. As Wolker had revived the nineteenth-century folk ballad, so Nezval had gone back to a much earlier genre, the epic poem. And in spite of its self-conscious modernity, the poem showed clear marks of its traditional origin. It is instructive to compare Nezval's poem of romantic travel with the prototype of the European epic of romance, Homer's Odyssey. In the classic epic the hero faces an ordeal which is imposed upon him from without: the basic problem is how to attain a set goal. For Odysseus the goal is to return to his home, resume his inheritance, and vindicate his honor. The path of return is strewn with obstacles: he must struggle with the spells of witches and the power of giants, as well as natural forces, before he meets and overcomes his mortal rivals, the suitors who dishonor his home. All these obstacles he overcomes by qualities traditional to the epic hero-physical strength and courage, cunning and deceit, eloquence and leadership. He is protected throughout by the favor of the gods, which enables him to walk unscathed, even through the land of the dead. His long journey is set partly in the real world of sailing men-the Eastern Mediterranean-and partly in the world of imagination. The fulfillment of his quest imposes upon him every

12. See Milan Blahynka, "Proměny Podivuhodného kouzelnika," Nový život, 1959, no. 1 , pp. $60-66$.

13. See the comment by Salda: “. . . an intensely colorful revolution formed from a wealth of vital instincts that spill over every form, that can have no end outside itself: a revolution like a wild chase after a quarry that is an impossible, unrealizable mirage. If anywhere in Czech poetry revolution is depicted as a saturnalia of the spirit, as chaos from which rises a star, it is here" ( $O$ nejmladš poesii české, p. 172). 
kind of danger and temptation; and among his most deadly perils, requiring all his cunning and resources, are the blandishments of lovely women, who would weaken his resolve and deter him from his goal. ${ }^{14}$

Certain of these features reappear in The Amazing Magician. In the fourth part the magician meets and overcomes his human foes in the struggle at the barricades on the day of revolution. In the sixth part his seven metamorphoses match the fantasy of the ancient epic, with their shape-shifting and transformations between men and animals. Nezval's really novel touch is to take his hero into the make-believe world of a Hollywood film. Like Odysseus, the magician descends to the world of the dead-twice in fact. His first contact is in the mortuary, where he seeks the aid of the dead in his struggle against death. Later he dies himself, and it is as one of the living dead that he passes through his remaining adventures. Like a traditional hero, the magician travels alone. He cannot risk a sexual attachment that would destroy his heroic powers. Detained and guided by a woman, he is united with her only when his quest is completed. As with other epic heroes, his birth is mysterious. Death, when it comes, returns him to the mystery of his origin. Every hero, in fulfilling his quest, fulfills himself.

In Nezval's poem the cause for which the hero acts is never defined: it implies the liberation of energy, as symbolized by the underground fountain, the freeing of humanity, seen physically in revolution, and the attainment of life-the new life of a reborn world. The magician's goal seems to be nothing less than to end the old ways in life, as in art-the contemporary cry of the Expressionists. Nezval thus seems to have transposed the ideas of political revolution and modernist art into an epic setting-half serious, half comic. The grotesque features of his epic were safeguarded from banality by their suspicion of intentional humor.

The fountain, which is mentioned repeatedly in the poem, is a symbol which looks forward to Nezval's surrealist phase. The magician, or artist, operates on a conscious level, but his work is governed by a mass of subterranean impressions, memories, and forgotten experiences. Ordinary folk are afraid to face these strange impressions, and thrust them down into oblivion, only to revisit them in the form of dreams. The artist, however, understands his debt to the past, and seeks to liberate from his own subconscious the forgotten mass. By liberating their flow, he is able to express ideas and visions which his readers will find strange but recognize as akin to their own experiences. Nezval often, in explaining his methods of composition,

14. For common thematic features of European epics see C. M. Bowra, Heroic Poetry (London, 1952; reprint, New York, 1966). For a study of the traps which seek to ensnare the returning hero see Agathe Thornton, People and Themes in Homer's Odyssey (London, 1970), pp. 16-37, and Jack Lindsay, The Clashing Rocks: A Study of Early Greek Religion and Culture and the Origins of Drama (London, 1965). 
revealed his debt to the childhood memories which it was his delight to explore: the world of the subconscious was the source of his rich fantasy. ${ }^{15}$

The hero of Nezval's poem was a figure who was to appear again in his work, notably in the poem Akrobat (1927). It was a modern, rather Dadaist view of the artist, no longer dignified or romantic, but in the semblance of a clown or conjurer. His view of the world is queer, and uninhibited by normal logic. Not only is the artist a man apart, but like the clown he emphasizes the difference by his strange style: his wonders are theatrical, marvelous, yet somehow not to be taken entirely seriously. The circus and the cinema screen produce their own form of magic-that is, a liberation from the normal categories of logic and the inhibitions of mundane life. To Nezval, the literary counterpart to the clown and the illusionist was the poet-liberator, creator of the new romanticism. ${ }^{16}$

In the criticism of European epic poetry a useful distinction has been drawn between two broad categories-that of heroic and nonheroic verse. ${ }^{17}$ The former is concerned especially with eminent men-princes, champions, leaders in war-who face their ordeal and overcome their enemies by specifically human qualities, acting in accordance with a code of honor approved by their own society. Nonheroic verse is more concerned with mystics, seers, and saints; their ordeal is symbolic or spiritual; their prowess does not come from physical strength but from their ability to tap or control nonhuman sources of power. Whereas the heroic prince prevails by his superior strength or wit, the seer fulfills his quest through his supernatural gifts, including his ability to subvert the course of nature. Such, in epic tradition, is the shaman-a figure well known in the folklore of Asia and Polynesia, as well as in Europe. A shaman is primarily a magician, a spellbinder, and as such his functions overlap with those of the poet or prophet. The shaman belongs to an elite sect, and is especially initiated into his vocation. When he is at work he attains a state of ecstasy, which enables him to enter the world above or below, then to return to the earth and relate his experiences. His symbol of power is the drum, which he makes himself and on which he plays during his ecstatic journey. By his powers he heals the sick, escorts the dead to the underworld, and mediates between the living and the dead.

15. Nezval, $Z$ mého żivota, pp. 96-97. See also his introduction to the second edition of Most (Prague, 1937), whose poems illustrate his ideas of recalled fantasy; Nezval's Chtèla okrást Lorda Blamingtona (Prague, 1930; reprinted in Dílo XXIV) is a fascinating revelation of the poet's subconscious world. For a discussion of his creative method see A. French, "The Czech Lyric Poet V. Nezval," Melbourne Slavonic Studies, 2 (1968): 21-38.

16. See, for example, his poem "Poetika" in Menši ri̊zová zahrada (Prague, 1926); Šalda, O nejmladši poesii české, p. 176.

17. See Hector M. and Nora Kershaw Chadwick, The Grozoth of Literature, 3 vols. (Cambridge, 1932-40), 3:702-3. 
Nezval's magician shows qualities, and passes through experiences, very much in the shamanist tradition. Like the shaman, the magician is marked out from others by the circumstances of his birth: his only human parent is a nun untouched by man. Her conception is symbolic, her delivery an illusion of the silver screen. Like the shaman, the magician's life is dominated by the magic number seven: there are seven acts to his poem; after seven years he goes out into the world; after another seven years he returns to tell of his wanderings; and after his initiation he passes through seven metamorphoses until he comes to the end of his journey. The shaman begins his ordeal by entering a trancethe transition from this world to that of the supernatural. The magician carries with him from childhood the vision of the staring cat which brings him strange dreams. After one such visitation he finds the Lake Lady at his side, and by her he is initiated to his final task. Like the shaman he descends to the land of the dead; first, symbolically, to the mortuary; then, during his metamorphoses, death comes to him on the coast of the Northern lands.

In describing the ancestral background of the magician, Nezval indicates an extraordinary cosmogony, which seems to be derived from traditional shamanist lore. The great mound which saw the conception of the magician stands above a shaft which stretches through the earth, past the fountain of life and the crystal caves, down to the antipodes. Through the shaft the moon is visible-a symbolic sickle. The cosmogony is again implied toward the end of the poem, when the magician completes his journey. Having traveled far on the horizontal plane, he reaches the moon, from which he views his own petrified corpse. Dead himself, he conducts a caravan of death, escorting the dead to their last home- a place of healing. Nezval's description may be compared with a picture of the shaman's traditional cosmos: "There are three great cosmic regions, which can be successively traversed because they are linked together by a central axis. This axis, of course, passes through an 'opening,' a 'hole'; it is through this hole that the gods descend to earth and the dead to the subterranean regions; it is through the same hole that the soul of the shaman in ecstasy can fly up or down in the course of his celestial or infernal journeys."18

Nezval's Amazing Magician reveals many other features which link it to traditional shamanic epics. The setting of the poem, the initiation, the ordeal, whereby the magician battles against death and escorts the souls of the departed, the meeting with his celestial wife (who speaks in a language comprehensible only to the initiated), the mystical nature of his quest, the magical recurring number seven, and above all, the nature of the hero-all are consistent with shamanic poetry. Within this very old framework of ideas Nezval

18. Mircea Eliade, Shamanism: Archaic Techniques of Ecstasy, trans. Willard R. Trask (London and New York, 1964), p. 259. 
incorporated some very modern features, and some of the poem's impact derives from the extraordinary paradox of their combination. Like the Proletarian poets, Nezval turned to the theme of revolution: one of the magician's early adventures was in the fighting at the barricades. But the revolution he seeks is more profound than any that exist on the physical plane. His feeling of loss, the quest which drives him forward, demands satisfaction at a deeper level. His search for himself runs parallel to the thrust of the underground fountain, striving upward toward the light. True liberation is that of the human spirit, and comes through art-the song of the shaman. Nezval reused the theme of revolution, but transformed it with the aid of fantasy. He also used the epic themes of the quest, the ordeal, and the trials of strength, but turned them into psychological adventures. It was another ten years before Nezval began to study psychoanalysis; but already in his first book Most he had shown a mastery of psychological symbolism, gained no doubt from creative literature. Uniting the traditional with the modernist, he expressed his ideas in a style illuminated by the technique of the contemporary silent films.

The Amazing Magician was the first of the great Poetist works. No less politically committed than the Proletarian poets, the Poetists expressed their views in a radically different way. Where Wolker's poems were consciously didactic, The Amazing Magician, like most epics, was intended for entertainment. The seriousness and conscious dedication of Proletarian poetry was matched by the gaiety and humor of Poetism. Where Wolker aimed above all for realism, Nezval exploited fantasy. Where the characters of the Proletarians tended to become stylized-types rather than people-the magician was, and consciously sought to be above all, himself. His quest was for the liberation of his own personality. Proletarian art expressed the values of the political movement which it echoed. This stressed the collective spirit, the subordination of the individual to the good of the mass, and the fulfillment of the individual endeavor in the common effort; hence one of its cardinal values was discipline, both in politics and in art. But the magician exemplified the revolt of the individual against the rules of convention. Where the Proletarians stressed discipline, the Poetists flirted with anarchy: instead of conformism they prized eccentricity. Proletarian literature brought to the center of the stage its own hero-the worker, heroic, self-sacrificing, disciplined, dedicated. $\mathrm{He}$ was one who conformed to the code of proletarian struggle, a figure not so much of joy as of suffering. The magician is the first of a series of Poetist figures (acrobats, harlequins, clowns) who in their characters exemplify a defiance of tradition, dignity, heroics, and taboos-any taboos. The revolution to which Wolker gave intellectual assent was based on a vision of social justice, and involved discipline and sacrifice. But its code of honor was traditional, almost puritanical. Nezval and the Poetists, much more radical than 
Wolker, swept aside all restraints-including, and especially, the restraint of reason. The Amazing Magician, like later surrealist works, makes its impact largely by the suspension of the logical and the expected. Its "heroism" was that of the charade; its "logic" that of the dream; its natural environment was not the city streets, but the borderland of the mind.

To some contemporary critics Poetism seemed a betrayal of art's social mission; poetry appeared to be vacating the political stage and abandoning a social role. The Poetists seemed to be withdrawing into a private world, or at least into a world where only the initiated could follow. But the shaman, had he been recognized, was a demonstratively public figure. Traditionally it was he who mediated between the mundane world of conscious life and the beyond -interpreting to the uninitiated the world of dreams, belief, magic, voodoo, and fantasy. The shaman's song is not of this world (the act of magic is a defiance of human limitations), but his power over others testifies to their belief in his authority. The miracles of which he tells are outside their experience, yet they recognize them as somehow familiar. Working by the methods of free association, stream of consciousness, and unrestrained fantasy, Nezval sought to create a topsy-turvy surrealist world which, if not comprehensible, was recognizable to readers, because it corresponded to the world of their own subconscious.

The Amazing Magician was Nezval's first full portrait of himself in the role of the poet-liberator. Later he preferred to speak with the voice not so much of the prophet as of the clown; but his whole career was a series of discarded masks, guises, and manifestoes, and this first portrait represents only one stage in his poetic development. In the poem he reveals a remarkable grasp of shamanic lore. His Amazing Magician survives from the debris of the literature of the early twenties-an enigmatic figure whose wonders outdid those of the contemporary screen, and whose words, like those of all shamans, were designed to make free. 